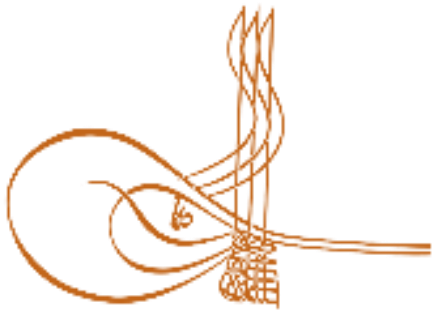

www.turkishstudies.net/social
Turkish Studies - Social Sciences

eISSN: $2667-5617$

Research Article / Araşttrma Makalesi

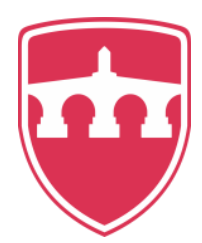

INTERNATIONAL

BALKAN

UNIVERSITY

Sponsored by IBU

\title{
Deneyim Boyutlarının Müşteri Memnuniyet ve Sadakatine Etkisi: Konya Şehir Merkezinde Bulunan 4 ve 5 Yıldızlı Konaklama İşletmelerinde Bir Araştırma*
}

\author{
The Effect of Experience Dimension to the Customer Satisfaction and Loyalty: A Study on 4 and 5 \\ Star Accommodation Enterprises in Konya City Center
}

\author{
Ferdi Bişkin** - Gülsün Duran ${ }^{* * *}$
}

\begin{abstract}
Experimental marketing, which place emphasis on sensual, emotional, intellectual, relational and behavioral dimensions of the products' and services' than their functional advantages, is started to apply to the tourism sector like several sectors. The purpose of this study is to determine the experience dimensions, which affect customer experience in accommodation enterprises, and to reveal the customer experience's effect on customer satisfaction and loyalty. The study was conducted with the participation of native customers staying in 4 and 5 starred accommodation enterprises located in the city center of Konya in 2018. Convenience sampling method is used and the sampling numbers are determined by stratified sampling method. Data are collected by survey. The 16 of 436 survey are eliminated due to their inaccuracy. In total, 420 survey are used for analysis. Correlation and regression analysis are used to determine the relationship and the impact among customers' experience dimensions, customer satisfaction and customer loyalty. The basic factors behind the customer satisfaction are customers' participation to the activities in educational field and alter the skills they already have or gain new skills (education), self-respect, recognition and strengthening social images (social satisfaction), add value to themselves and their environment (altruistic). When the relationship between the customer experience sub dimension and customer loyalty is examined, it is concluded that education, social satisfaction, social interaction, and altruistic dimensions effect customer loyalty in a positive way. In addition to the education, social satisfaction and altruistic experience factor, which provides customer satisfaction, interaction experience (social interaction) among customer, other customers and employees during the stay is a factor, which provides customer loyalty.
\end{abstract}

\footnotetext{
* Bu makale, Necmettin Erbakan Üniversitesi Sosyal Bilimler Enstitüsü Turizm İşletmeciliği Yüksek Lisans Programında kabul edilen, "Deneyimsel Pazarlama Kapsamında Konya Şehir Merkezinde Bulunan Otellerde Bir Araştırma" isimli yüksek lisans tezinden üretilmiştir.

${ }_{* *}$ Dr. Öğr. Üyesi, Necmettin Erbakan Üniversitesi Turizm Fakültesi, Turizm İşletmeciliği Bölümü Asst. Prof. Dr., Necmettin Erbakan University Faculty of Tourism, Tourism Management ORCID 0000-0002-9864-751X

fbiskin@erbakan.edu.tr

*** Lisanüstü Öğrencisi, Necmettin Erbakan Üniversitesi Sosyal Bilimler Enstitüsü Turizm İşletmeciliği Anabilim Dalı Graduate Student, Necmettin Erbakan University Institute of Social Sciences, Tourism Management ORCID 0000-0002-0179-5154

gulsun_ocak@hotmail.com

Cite as/ Atıf: Bişkin, F., Duran, G. (2020). Deneyim boyutlarının müşteri memnuniyet ve sadakatine etkisi: Konya şehir merkezinde bulunan 4 ve 5 y1ldızlı konaklama işletmelerinde bir araştırma, Turkish Studies - Social, 15(1), 817-836. https://dx.doi.org/10.29228/TurkishStudies.37890

Received/Geliş: 01 October/Ekim 2019

Accepted/Kabul: 25 February/Şubat 2020

Copyright $(C)$ INTAC LTD, Turkey

Checked by plagiarism software

Published/Yayın: 29 February/Şubat 2020

CC BY-NC 4.0
} 
Structured Abstract: Today's economy's foundation is based on the approaches that accepts the consumption as an experience process and marketing activities form accordingly. Experimental marketing, which place emphasis on sensual, emotional, intellectual, relational and behavioral dimensions of the products' and services' than their functional advantages, is started to apply to the tourism sector like several sectors.

Literature mostly consists of the studies which examines the experience dimension that enterprises serve and the effect of these dimensions to the buying behavior. To determine the effects of experience on customer satisfaction and loyalty indicates a considerable need on the tourism sector. Based on this need, study seeks answers on questions such as; what are the factors that affect customer experience in accommodation enterprises? How these effects impress customer satisfaction and loyalty? Within this context, the purpose of this study is to determine the experience dimensions, which affect customer experience in accommodation enterprises, and to reveal the customer experience's effect on customer satisfaction and loyalty.

The study was conducted with the participation of native customers staying in 4 and 5 starred accommodation enterprises located in the city center of Konya in 2018 . The study held on by using descriptive research technique. To identify the samples of the study, the total customer number of 4 and 5 star accommodation enterprises' of the years 2015, 2016, 2017 were determined then, the arithmetic mean was calculated. According to this, the total number of customers accommodate in 2015, 2016 and 2017 is 921.630 and annual customer number is 307.210 on average. $95 \%$ of confidence level is targeted in sample so 420 customer participation is provided. The observation numbers, which were obtained from the customers who accommodate in 4 and 5 star accommodation enterprises in Konya city center, were determined by stratified sampling. Accordingly, the numbers of customers who accommodate on 4 and 5 star hotels are determined and the each accommodation enterprise group's customer number ratio in the universe is used as base. According to this, the ratio of customer number who accommodate on 4 star accommodation enterprises is $59 \%$ in the last three years. The ratio of customer number who accommodate on 5 star accommodation enterprises $40.4 \%$ in the last 3 years. According to these ratios, 250 of 420 samples consists of customers who accommodate in 4 star accommodation enterprises and 170 of it consists of customers who accommodate in 5 star accommodation enterprises.

A survey form is used as data collection tool in the study. The survey form is consists of 65 items to determine the relationship and the impact among customers' experience dimensions, customer satisfaction and customer loyalty. Experience scale of customers adapted from the work of Çelik (2013), the customer satisfaction and loyalty scale is adapted from the work of Erbaş (2010). Participants are demanded to rate all the items on a five point Likert scale as $1=$ strongly disagree, $5=$ strongly agree.

Before the study, a pilot study on 20 people was held to support the validity and reliability of the scale.

The data obtained were analyzed by SPSS 20.0 programme. Correlation and regression analysis were held to determine relationship and impact among the customer experience dimensions, customer satisfaction and customer loyalty.

As a result of the study it is appears that the factors that affect customer experience in accommodation enterprises are; ergonomic, education, esthetics, amusement, social satisfaction, social interaction, get away and altruistic.

Education, social satisfaction and altruistic variables, which are the sub dimensions of customer experience, affect customer satisfaction on significant level statistically. No other significant effect of the other sub dimensions of customer experience on customer satisfaction are found. In other words, education, social satisfaction and altruistic experience of customers effect customer satisfaction positively. When the coefficients table is examined, the greatest contribution to customer satisfaction is education. Customers' participation to activities in the field of education in accommodation enterprises, result in developing their skills, gaining new skills (education), self-respect, recognition, strengthen the social images (social satisfaction), bring a value to themselves and their environments (altruistic experience) and these are the basic factors behind their satisfaction.

Education, social satisfaction and altruistic variables, which are the sub dimensions of customer experience, affect customer loyalty on significant level statistically. No other significant effect of the other sub dimensions of customer experience on customer loyalty are found. When the coefficients table is examined, the greatest contribution to customer loyalty is education experience as in the customer satisfaction. In addition

Turkish Studies - Social, 15(1) 
to education, social satisfaction and altruistic experience, which also provides customer satisfaction, customers' interaction experience (social interaction) with other customers and employees while they are in the same enterprise throughout the accommodation, is determined as a factor that provides customer loyalty.

The results of the study put forward that the education, altruistic and social satisfaction dimensions of customer experience have an effect on both customer satisfaction and customer loyalty. These results are also in accordance with the research results of Holbrook (1994 ve 2005), Schmitt (1999) and Brady and Cronin (2001) From this angle, it can be stated that the applications that develop education, social satisfaction, altruistic and social experience dimensions stimulate customer satisfaction and customer loyalty. Therefore, accommodation enterprises should strengthen their 'education' by providing educational and instructive activities that make a sensation on customers and evoke their learning instincts, strengthen their altruistic by presenting environment friendly product and services and their social satisfaction by establishing relationships that enhance customers' self-respect and social interaction by providing communication among customers. On the other hand, the variety of customer portfolio and strengthen the other experience dimensions by considering customer needs and expectations which are changing everyday also has a great importance.

It is expected that the obtained results contribute to literature in experimental marketing field. Moreover, it can be a guide to the hospitality enterprises who want to increase customer satisfaction and loyalty and their profit by means of experimental marketing.

There are some limitations of the study. Firstly, it is limited on eight dimensions of the customer experience. The experience dimensions can be enhanced in the future. Secondly, the sample consists of local customers who accommodate on 4 and 5 star hotels. The results may be more general and healthy if the study was held among the hotels of the different cities and statues with the customers who have different ethnic and cultural backgrounds. Therefore, its contribution to the experimental marketing applications would be much. Also besides quantative researches, if the qualitative researches on the tourism enterprises, which apply experimental marketing, have done, there would be much deeply investigation of the topic.

Keywords: Experience Dimensions, Experimental Marketing, Accommodation Enterprises, Customer Satisfaction, Customer Loyalty.

Öz: Tüketiciye sunulan mal ve hizmetlerin işlevsel yararlarından ziyade, duyusal, duygusal, düşünsel, ilişkisel ve davranışsal boyutlarına önem veren deneyimsel pazarlama, birçok sektörde olduğu gibi turizm sektöründe de uygulanmaya başlanmıştır. Bu araştırmanın amacı; konaklama işletmelerinde müşteri deneyimini etkileyen deneyim boyutlarını belirleyerek, müşteri deneyiminin müşteri memnuniyeti ve sadakatine etkisini ortaya koymaktır. Araştırma, 2018 yılında Konya şehir merkezinde yer alan 4 ve 5 yıldızlı konaklama işletmelerinde konaklayan yerli müşterilerin katılımıyla gerçekleştirilmiştir. Örneklem yöntemi olarak kolayda örnekleme yöntemi kullanılmış, örneklem sayıları ise tabakalı örnekleme yöntemiyle belirlenmiştir. Veriler anket yoluyla toplanmış, geri dönen 436 anketten 16 tanesi eksik ve hatalı bulunarak elenmiştir. Toplam 420 anket analiz için kullanılmıştır. Müşteri deneyim boyutları, müşteri memnuniyeti ve müşteri sadakati arasındaki ilişki ve etkiyi tespit edebilmek için korelasyon ve regresyon analizleri yapılmıştır. Müşterilerin, konaklama işletmelerinde eğitim alanındaki faaliyetlere katılarak sahip oldukları becerileri geliştirme ya da yeni beceriler kazanma (eğitim), öz saygı, tanınma ve sosyal imajlarını güçlendirme (sosyal tatmin), kendilerine ve çevrelerine değer katma (alturistik) deneyimlerinin, memnuniyetlerinin ardındaki temel faktörler olarak ortaya çıkmıştır. Müşteri deneyim alt boyutları ile müşteri sadakati arasındaki ilişki incelendiğinde; eğitim, sosyal tatmin, sosyal etkileşim ve alturistik boyutlarının müşteri sadakatini olumlu yönde etkilediği sonucuna ulaşılmıştır. Aynı zamanda müşteri memnuniyetini de sağlayan eğitim, sosyal tatmin ve alturistik deneyim faktörlerine ek olarak, müşterilerin konaklama süresince aynı işletmede bulunduğu diğer müşteriler ve çalışanlarla etkileşim deneyimi (sosyal etkileşim), müşteri sadakatini sağlayan bir faktör olarak ortaya çıkmıştır.

Anahtar Kelimeler: Deneyim Boyutları, Deneyimsel Pazarlama, Konaklama İşletmeleri, Müşteri Memnuniyeti, Müşteri Sadakati. 


\section{Giriş}

İşletmeler varlıklarını sürdürebilmek, rekabet güçlerini korumak ve güçlendirmek, hedeflenen kârlılık oranlarını yakalayabilmek için geleneksel pazarlama anlayışlarını değiştirmek zorunda kalmışlardır. $\mathrm{Bu}$ kapsamda, işletmeler artık ürünlerin işlevsel özelliklerinden ya da faydalarından ziyade, tüketicilere yaşattıkları benzersiz deneyimler üzerinden farklılık ve müşteri sadakatini oluşturmaya çalışmaktadırlar.

Günümüz ekonomisinin temelleri, tüketimi bir deneyim süreci olarak kabul eden yaklaşımlara dayanmaktadır. Bu bağlamda, deneyimsel pazarlama eğilimi, işletmelerin tüketicilere sunduğu deneyimlerin oluşturulmasında ve tüketiciye sunulmasında öncülük etmektedir. Günümüzde tüketiciler duygusal canlılar olarak değerlendirilmeye başlandığı için deneyimsel pazarlama yaklaşımıyla tüketimi keyifli bir hale getirmek ve benzersiz deneyimler sunmak amaçlanmıştır.

Deneyimsel pazarlama, müşterileri memnun etmekten öte, onlarda işletmeye karşı bir sadakat yaratmayı hedef edinmiştir. Deneyim ekonomisi içerisinde, sadece müşteri memnuniyetini dikkate alan geleneksel pazarlama eğilimleri daha az yer bulmaktadır. Pazarlama uzmanları, müşteri sadakatini sağlamak için bu geleneksel pazarlama eğilimleri yerine, müşterilere benzersiz, eğlenceli ve anlamlı deneyimler sunarak müşteri sadakati yaratmayı amaçlamaktadırlar (Tsai, 2005: 433).

Araştırma, konaklama işletmelerinde müşteri deneyimini etkileyen deneyim boyutlarını belirleyerek, müşteri deneyiminin müşteri memnuniyeti ve sadakatine etkilerini ortaya koymay1 amaçlamaktadır. Memnun müşterilerin mal ve hizmet satın aldıkları işletmelere sadakat göstermeleri mümkündür. Memnun müşteriler oluşturmanın önemli etkenlerinden biri de müşterilere olumlu deneyimler yaşatmaktır. Olumlu deneyimler yaşayan müşteriler, memnuniyetleri sonrasında ilgili işletmelere sadakat geliştirebileceklerdir. Bu sebeple, işletmelerin müşterilerini memnun etmek için onlar üzerinde hangi deneyim boyutlarının etkili olduğuna tespit etmeleri ve bu boyutlara dikkat etmeleri, sadık müşteriler oluş̧urmaları için gereklidir. Konaklama hizmeti alan müşsteriler kısa süre içerisinde pek çok deneyimi yaşayabilirler. Aynı zamanda, işletmelerin müşteri deneyim boyutları üzerine eğilmesi, işletme kaynaklarının verimli kullanılmasını da sağlayabilecektir. Bu sebeplerle, araştırmanın, deneyimsel pazarlamada müşteri deneyim boyutları hakkındaki toeriyi test etmesi ve uygulamada, konaklama işletmelerine önemli olabilecek çıktılar sunması beklenmektedir.

Araştırmanın ilk bölümünde, müşteri deneyim boyutlarıyla ilgili literatür özetlenmiştir. Daha sonra deneyimsel pazarlama ve müşteri deneyim boyutlarıyla ilgili kavramsal bilgilere yer verilmiş̧ir. Bunların ardından, araştırmanın metodolojisinden bahsedilmiş ve araştırma hipotezlerinin test edildiği analizler paylaşılmıştır.

\section{Literatür İncelemesi}

Araştırmada, deneyimsel pazarlama eğiliminin bütün yönleriyle incelenebilmesi amacıyla bir literatür taraması yapılmıştır. $\mathrm{Bu}$ çerçevede, deneyimsel pazarlama alanındaki araştırmalar: Schmitt (1999), Brady ve Cronin (2001), Holbrook (2005), Holbrook (2006), Tsaur vd. (2007), Oh (2007) incelenmiştir.

Çeltek (2010) çalışmasında, Türkiye'de faaliyet gösteren 4 ve 5 yıldızlı otel işletmelerinin uyguladıkları deneyim türlerini, deneyim boyutlarını ve işletmelerin hangi temaları kullandıklarını belirlemeyi amaçlamıştır. Araştırma sonuçlarına göre, müşterilerin deneyim boyutları ve deneyim türleri ile deneyim sağlayıcıların sunduğu deneyim türlerinde farklılıklar olduğu tespit edilmiştir.

Çelik (2013) çalışmasında, tur operatörlüğü yapan işletmelerin Asya kıtasından gelen turistlere sundukları deneyimsel değer unsurlarını belirlemeyi amaçlamıştır. Verilerden elde edilen sonuçlara göre, deneyimsel değer unsurlarının müşteri memnuniyeti, müşteri tatmini ve müşteri sadakatini olumlu yönde etkilediği tespit edilmiştir. 
Brady ve Cronin (2001) çalışmalarında, müşteri odaklı çalışmanın çalışan performansına ve davranışlarına ayrıca tüketici davranışlarına etkilerini incelemişlerdir. 649 tüketiciden alınan cevaplar doğrultusunda, müşteri odaklı çalışmanın müşteriye sunulan hizmetin performansı ve müşteri değerlendirmeleri ile doğrudan ilişkili olduğu sonucuna ulaşılmıştır.

\section{Deneyimsel Pazarlama}

Schmitt (1999) deneyimsel pazarlamayı, müşterilerin yaşadıkları deneyimler ve çeşitli uyarımlar sonucu bir markanın ürünlerini satın alma eylemi olarak tanımlamaktadır (Artuğer, Çetinsöz, Ercan ve Kendir, 2014: 107-111). Yuan ve Wu (2008: 388)'ya göre deneyimsel pazarlama, işletmelerin fiziksel çevreyi ve işlemsel süreçleri müşterilerin çeşitli deneyimler edinmesini sağlayacak şekilde tasarlamasını öngören bir pazarlama taktiğidir. Smilansky (2009: 5) ise deneyimsel pazarlamayı, müşteri istek ve ihtiyaçlarının kârlılık hedefleri gözetilerek tanımlanması, etkin ve verimli bir şekilde karşılanması ve hedef kitleye arzu edilen değerlerin kazandırılması süreci olarak tanımlamaktadır.

Deneyimsel pazarlama, müşterilerin satın alma kararlarına etki eden faktörleri tespit ederek, bunları gerçek ve somut deneyimlerle sunmayı amaçlamaktadır (Williams, 2006: 485-486). Deneyimsel pazarlama ayrı ayrı her bireyin kendi kişiliği ile bağlantılıdır. Bireyler deneyimsel pazarlama sayesinde kendi kişiliklerini ortaya koyabilmekte, tecrübelerinden anlam çıkartabilmekte ve satın alma kararlarını buna göre verebilmektedirler (Aykaç ve Kervenoael, 2008: 4).

Schmitt, deneyimsel pazarlamanın kendine özgü temel dört özelliği bulunduğundan söz etmektedir (Sharma ve Sharma 2011: 3).

1. Tüketici deneyimi: Deneyimsel pazarlamanın odak noktası tüketici deneyimleridir. Deneyimler bireylere, duygusal, ilişkisel, bilişsel, davranışsal ve duyusal değerler kazandırmaktadır.

2. Bütünsel bir deneyim olarak tüketim: Deneyimsel pazarlamayla kazandırılması hedeflenen deneyim, belirli bir hizmetin sunulmasından ya da ürünün tüketiminden sonra oluşmaktadır. Deneyimsel pazarlamada tüketiciler havlu, şampuan, banyonun tasarımı, banyo kremi, el kremi ve sabunu ayrı ayrı değerlendirmemektedirler. Onlar için önemli olan duş alırken banyonun sunduğu rahatlık ve düzendir.

3. Tüketiciler duygusal ve rasyoneldir: Deneyimsel pazarlamada tüketiciler bir markay1 tercih ederken çoğu zaman rasyonel ve duygusal davranmaktadırlar. Rasyonel kararlar da duygular sonucu ortaya çıkmaktadır. Bunun nedeni, tüketim deneyimini fantezi, his ve eğlence gibi olguların yönlendirmesidir.

4. Çok yönlü yöntemler: Deneyimsel pazarlamada çeşitli pazarlama araştırma yöntemleri kullanılabilmektedir. Tata Indica Vista gibi çok eski model bir arabada bile test sürüşü yapan kişilerin her birinin his, duygu, duyum ve davranışları bütün yönleriyle incelenmektedir.

Deneyimsel pazarlama kişilerin kültürel özellikleriyle birlikte değerlendirmekte ve kişilerin mantıklarından çok, duygularıyla ilgilenmektedir. Deneyimsel pazarlamada genel amaç; tüketicilerin yaşayacağ deneyimlere odaklanarak, bu deneyimleri geliştirmek ve iyileştirmektir.

Deneyimsel pazarlama ile geleneksel pazarlama anlayışı arasında bakış açısı ve uygulama anlamında bazı farklılıklar bulunmaktadır. Bu farklılıklar Tablo 1'de verilmiştir. 
Tablo 1: Geleneksel Pazarlama ile Deneyimsel Pazarlamanın Karşılaştırılması

\begin{tabular}{ll}
\hline Geleneksel Pazarlama & Deneyimsel Pazarlama \\
\hline $\begin{array}{l}\text { Genellikle işlevsel özelliklere ve sağlanan } \\
\text { faydaya odaklanmaktadır. }\end{array}$ & $\begin{array}{l}\text { Algılara dayalı müşteri deneyimleri oluşturma } \\
\text { üzerine odaklanmaktadır. }\end{array}$ \\
\hline $\begin{array}{l}\text { Ürün grupları ve rakipler dar bir çerçevede } \\
\text { tanımlanmakta ve daha çok, yakın çevredeki } \\
\text { direkt alternatifler dikkate alınmaktadır. }\end{array}$ & $\begin{array}{l}\text { Tüketim olgusu bir bütün olarak } \\
\text { değerlendirilmektedir. }\end{array}$ \\
\hline $\begin{array}{l}\text { Müşteriler sadece mantıklı ve rasyonel karar } \\
\text { vericiler olarak görülmektedir. }\end{array}$ & $\begin{array}{l}\text { Müşterilerin rasyonel kararlarının yanında, } \\
\text { duyusal yönleri de dikkate alınmaktadır. }\end{array}$ \\
\hline $\begin{array}{l}\text { Yöntemler genellikle analitik, nicel ve sözel } \\
\text { olarak kullanılmaktadır. }\end{array}$ & $\begin{array}{l}\text { Çok yönlü veya seçmeli yöntemler } \\
\text { kullanılmaktadır. }\end{array}$ \\
\hline
\end{tabular}

Kaynak: (Artuğer vd., 2014:109).

Geleneksel pazarlama, yüzeysel işlevsel özellik ve faydalara odaklanırken deneyimsel pazarlama müşteri deneyimlerine odaklanmaktadır. Deneyim, deneyimsel pazarlamanın temel bileşenidir (Yuan ve Wu, 2008: 390). Deneyimler müşteriye; duyusal, duygusal, davranışsal, düşünsel ve ilişkisel değerler sağlayarak ürünün sağladığı işlevsel özelliklerin yerini almaktadırlar. Bu yaklaşım, marka, rekabet ya da ürün temelli olmaktan ziyade, tüketim bütünsel bir deneyim olarak değerlendirilmektedir. Geleneksel pazarlamada müşteriler ve pazar hakkında veri toplamak için analitik ve nicel yöntemler kullanılırken deneyimsel pazarlamada bu yöntemlere ek olarak nitel veri toplama yöntemleri ve deneyimsel tasarım yöntemleri de kullanılmaktadır (Çiçek, 2015: 49).

\section{Müşteri Deneyim Boyutları}

Deneyimlere katılım düzeyleri dikkate alındığında deneyim boyutları yatay ve dikey olmak üzere iki gruba ayrılmaktadır. Dikey grup, sarmalanma ve özümseme olarak iki alt gruba ayrılırken; yatay grup, aktif ve pasif katılım olarak iki alt gruba ayrılmaktadır (Şekil 1). Yatay eksendeki boyutlar müşterinin deneyime katılım düzeyini göstermektedir. Pasif katılımda tüketici izleyici ya da gözlemci rolündeyken, aktif katılımda tüketici deneyim etkinliğine bizzat katılarak deneyimi yaşamaktadır. Örneğin, bir müzeye giden ve oradaki eserleri inceleyen bir ziyaretçi pasif katılım gerçekleştirirken, Fethiye Babadağ'da düzenlenen yamaç paraşütü etkinliklerine katılarak paraşütle atlayan ziyaretçi aktif katılım gerçekleştirmektedir (Lin, 2006: 25-26).

Dikey eksendeki boyutlar ise sarmalanma ve özümsemedir. Sarmalanmada tüketici deneyimleri bizzat deneyimlerken, özümsemede deneyimi zihninde yaşayarak deneyimlemektedir. Örneğin, İtalya'nın Venedik şehrini anlatan bir gezi ya da tanıtım programını izleyen ve kendini gondola binerken hayal eden bir tüketici, deneyimi zihninde yaşamakta ve deneyimin özümseme boyutunda yer almaktadır. Ancak Venedik şehrine giderek gondola binen, Venedik'in sokaklarında dolaşan ve San Marco Meydanı'nda martılara yem atan bir tüketici deneyimin bir parçası haline gelmekte ve deneyimle sarmalanmaktadır (Güney, 2015: 37). 


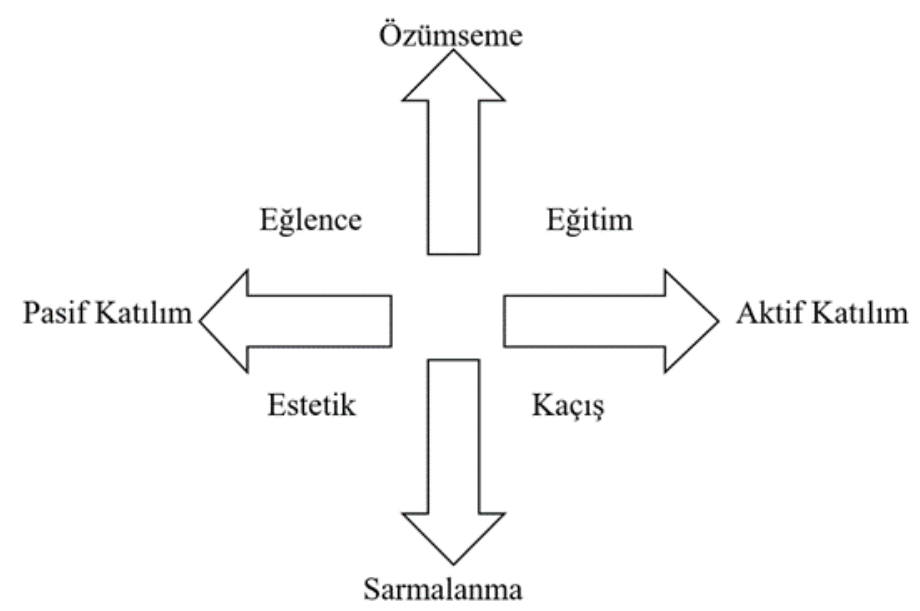

Şekil 1: Deneyim Boyutlar1

Kaynak: (Oh, Fiore, Jeoung, 2007:121).

Ĕ̆lence deneyim boyutu: Yatay eksendeki pasif katılımla dikey eksendeki özümseme ilişkisinin bir araya gelmesiyle oluşmaktadır. Bu boyuta bir bale gösterisini izlemeye gelen tüketici örnek gösterilebilir. Gösterinin düzenlenmesinde tüketici herhangi bir faaliyette bulunmadığı için pasif katılım sergilemekte ve sahnede yer alıp gösterinin bir oyuncusu olmadığı için de özümseme ilişkisi içerisindedir (Başar, 2015: 11). Eğlence deneyim boyutu; tiyatro gösterileri, konserler, festivaller, kuş gözlemciliği, yaban hayatı gözlemleme, sanatsal etkinlikler, sokak sergileri, müze ziyaretleri ve sinema gibi birçok etkinliği içermektedir (Çeltek, 2010: 79).

Ĕ̆itim deneyim boyutu: Aktif katılım ve özümseme ilişkisinin bir araya gelmesi sonucu oluşmaktadır. Eğitim alanındaki faaliyetlere katılımcılar aktif olarak katılmak durumundadırlar. Bu deneyim boyutunda katılımcılar sahip oldukları becerileri geliştirirler ya da yeni beceriler kazanırlar. Kayak eğitimi incelenecek olursa, katılımcı aktif olarak faaliyette yer almak durumundadır fakat bir kayak eğitmeni ya da kayak sporcusu olmadığ iç̧in ilişki özümseme düzeyindedir. Eğitim programları, gayri resmi dersler, rehberli turlar, kırsal çiftlikler, interaktif müzeler, hobi kursları, yemek pişirme kursları bu deneyim boyutunda yer alan bazı etkinliklerdir (Williams, 2006, Çeltek, 2010: 9).

Estetik deneyim boyutu: Sarmalanma ilişkisi ve pasif müşteri katılımı sonucunda ortaya çıkmaktadır. Bir dağ oteline kayak yapmaya giden bir müşteri ele alındığında; herhangi bir kayak etkinliğine katılmadığı ve kayma faaliyetini kendi başına gerçekleştirdiği için pasif katılım içerisinde olmakta fakat kayma eylemini karın üzerinde deneyimlediği için sarmalanma ilişkisi içerisinde olmaktadır (Başar, 2015: 11). Bu deneyim boyutu doğa gezileri, özel tasarlanmış otel lobileri ve odaları, temalı odalar, bahçe tasarımları gibi etkinliklerle deneyimlenebilmektedir (Çeltek, 2010: 79).

Kaçış deneyim boyutu: Aktif katılım ve sarmalanma ilişkisi sonucunda ortaya çıkmaktadır. $\mathrm{Bu}$ deneyim boyutunda sarmalanma ilişkisi çok daha güçlüdür. Deneyimin yaşatılmasında çevre ve diğer uyaranların etkisi önemli düzeydedir. Tematik parklar, kumarhaneler, internet sohbet odaları, dış mekân oyun alanları tüketicilerin izlemekten ziyade, eylemlerde bulundukları alanlardır. Bu nedenle bu alanlarda kaçış deneyim boyutu gerçekleşmektedir (Deligöz, 2016: 74). Bungee jumping, su sporları, golf, masaj ve SPA (Sanus Per Aquam-Su ile gelen sağlık) aktiviteleri, at ve bisiklet turları, dağcılık, salon sporları, macera turizmi, yoga gibi etkinlikler bu deneyim boyutuna örnek gösterilebilir (Çeltek, 2010: 79). 
Başlangıçta bu dört boyutu içeren deneyim kavramı, deneyimin ergonomiklik, sosyal tatmin, sosyal etkileşim ve alturistik yönlerini ortaya koyan çalışmalarla birlikte genişlemiştir.

Ergonomiklik: Ergonomiklik kavramı; verimlilik, mükemmellik ve ekonomiklik alt başlıkları altında incelenebilir. Verimlilik değeri, en az kaynakla ve en kısa sürede en fazla faydayı sağlamak olarak açıklanabilir (Holbrook, 1994: 35). Mükemmellik değeri; kalite, müşteri beklentilerinin karşılanması ve kusursuz hizmetle ilgilidir. (Brady ve Cronin, 2001: 245). Ekonomik değer, sunulan hizmete ödenen bedel ile elde edilen faydanın ilişkilendirilme derecesini ifade eder (Holbrook, 1994: 35).

Sosyal Tatmin: Bireyin öz saygısı, tanınması ve sosyal imajı ile ilgilidir. (Holbrook, 1994: 36; Schmitt, 1999: 66).

Sosyal Etkileşim: Birey, konaklama süresince aynı işletmede bulunduğu diğer müşteriler ve çalışanlarla etkileşim halindedir. Bu etkileşim, bireyin konaklama deneyimini etkilemektedir (Schmitt, 1999: 66).

Alturistik: İçsel ve dışsal yönlü olmayı, bireyin kendisine ve çevresine değer katmasını ifade etmektedir. Alturistik değer, turistik tüketimlerde bireyin doğaya dost tüketimlerde bulunmasiyla ve doğaya dost ürünleri kullanan işletmeleri tercih etmesiyle ölçülebilir. Bireyin ekolojik işletmeleri tercih etmesi alturistik değer edinmesini sağlayacaktır (Holbrook, 2005: 49).

\section{Yöntem}

$\mathrm{Bu}$ başlık altında, araştırmada kullanılan yöntem hakkında bilgilere yer verilmiştir.

\section{Evren ve Örneklem}

Araştırmanın evreni, 2018 yılında Konya şehir merkezinde bulunan 4 ve 5 yıldızlı konaklama işletmelerinde konaklayan yerli müşterilerdir. Örneklemi tespit etmek için 2015, 2016 ve 2017 yıllarında Konya şehir merkezinde bulunan 4 ve 5 yıldızlı konaklama işletmelerinde konaklayan müşterilerin sayıları, Konya Valiliği İl Kültür ve Turizm Müdürlüğü’nden sağlanmıştır. Konya şehir merkezinde bulunan 4 ve 5 yıldızlı yatırım ve işletme belgeli toplam 14 konaklama işletmesi olduğu tespit edilmiştir. Bu verilere göre, 2015, 2016 ve 2017 yıllarında Konya şehir merkezinde bulunan 4 ve 5 yıldızlı konaklama işletmelerinde konaklayan müşterilerin sayılarının aritmetik ortalaması, 307.210 olarak belirlenmiştir. Örneklem büyüklüğünün hesaplanmasında önceden hazırlanmış örneklem büyüklükleri tablosundan faydalanılmıştır. Bu tablo incelendiğinde, $\% 95$ güven düzeyinde 307.210 kişilik bir çalışma evreninden 384 kişilik bir örneklem büyüklüğüne ulaş1lması gerekmektedir (Yazıcıŏ̆lu ve Erdoğan, 2004: 50). Bu doğrultuda, geri dönen 436 anketten 16 tanesi eksik ve hatalı bulunarak elenmiş, toplam 420 anket analiz için kullanılmıştır.

4 ve 5 yıldızlı otellerde konaklayan müşterilerin örneklem sayıları ise tabakalı örnekleme yöntemiyle belirlenmiştir. Bu doğrultuda her bir konaklama işletmesi grubundaki müşteri sayısının evren içindeki oranı temel alınarak 420 gözlemlik bir örneklem büyüklügüüün 250 gözlemlik tabakasını 4 yıldızlı konaklama işletmelerinde konaklayan müşteriler; 170 gözlemlik tabakasını ise 5 yıldızlı konaklama işletmelerinde konaklayan yerli müşteriler oluşturmuştur. Tabakalı örneklem yöntemine bağlı kalmak koşuluyla anket formları araştırmacı tarafindan müşterilere birebir ulaşılarak, konaklama işletmelerinden, tur operatörü olan işletmelerden ve müşterilerini bu konaklama işletmelerinde ağırlayan diğer sektörlerdeki işletmelerden yardım alma yoluyla doldurtulmuştur.

\section{Ölçek}

Araştırmada veri toplama aracı olarak anket formu kullanmıştır. Anket formu, müşterilerin edindiği deneyim boyutlarının, müşteri memnuniyetinin ve müşteri sadakatinin belirlenmesine yönelik olup 65 maddeden oluşmaktadır. Müşterilerin edindiği deneyim ölçeği Çelik’ten (2013) 
uyarlanmıştır. Müşteri memnuniyeti ve müşteri sadakati ölçeği ise Erbaş’ın (2010) Starbucks zincir mağazalarının yaşattığı deneyim tutum ölçeğinden uyarlanmıştır. Katılımcıların tüm maddeleri 1= kesinlikle katılmıyorum, 5= kesinlikle katılıyorum olacak şekilde beşli likert ölçeğinde derecelendirmeleri istenmiştir.

Maddelerin anlaşılırlığının test edilebilmesi için bir pilot uygulama yapılmıştır. Bu uygulama 01-15 Haziran 2017 tarihleri arasında Konya Mesleki ve Teknik Anadolu Lisesi öğretmenleriyle yapılmıştır. Anket formunun anlaşılabilirlik durumunu değerlendirebilmek ve uygulamada yaşanabilecek sorunları belirleyerek bu sorunlara çözümler üretebilmek amaciyla yapılan bu pilot uygulamaya 20 öğretmen katılmıştır. Anket formları istatistik paket programı aracılığı ile analiz edilmiştir. Faktör analizi temel bileşenler ve varimax rotasyonu yöntemi ile güvenirlik analizi Cronbach Alpha katsayısı ile yapılmıştır.

\section{Araştırmanın Modeli}

Araştırmada önerilen model (Şekil 2.), deneyim boyutlarının müşteri deneyimini olumlu yönde etkilediğini ve bu durumun müşteri memnuniyetini ve sadakatini artıracağını varsaymaktadır.

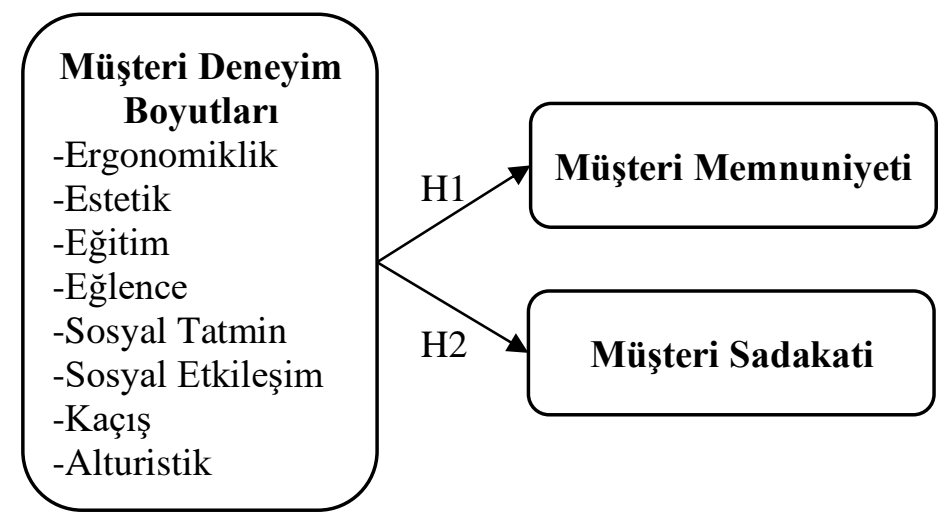

Şekil 2: Araştırmanın Modeli

Araştırma modeli kapsamında aşağıdaki hipotezler geliştirilmiştir:

H1: Müşteri deneyiminin ergonomiklik (a), eğitim (b), estetik (c), eğlence (d), sosyal tatmin (e), sosyal etkileşim (f), kaçış (g), alturistik (h) boyutunun müşteri memnuniyeti üzerinde anlamlı etkisi vardır.

H2: Müşteri deneyiminin ergonomiklik (a), eğitim (b), estetik (c), eğlence (d), sosyal tatmin (e), sosyal etkileşim (f), kaçış (g), alturistik (h) boyutunun müşteri sadakati üzerinde anlamlı etkisi vardir.

\section{Bulgular}

Bu başlık altında, analiz sonuçlarına yer verilmiştir.

\section{Cevaplayıcıların Sosyo-Demografik Özellikleri} verilmiştir.

Araştırmaya katılan turizm müşterilerinin sosyo-demografik özellikleri Tablo 2'de 
Tablo 2: Cevaplayıcıların (Müșteri) Sosyo-Demografik Özellikleri

\begin{tabular}{|c|c|c|c|c|c|c|c|}
\hline $\begin{array}{l}\text { Demografik } \\
\text { Değişkenler }\end{array}$ & Değer & Say 1 & Yüzde & $\begin{array}{l}\text { Demografik } \\
\text { Değişkenler }\end{array}$ & Değer & Say1 & Yüzde \\
\hline \multirow{3}{*}{ Cinsiyet } & Kadın & 161 & 38,3 & \multirow{3}{*}{$\begin{array}{l}\text { Medeni } \\
\text { Durum }\end{array}$} & Evli & 244 & 58,1 \\
\hline & Erkek & 259 & 61,7 & & Bekâr & 176 & 41,9 \\
\hline & Toplam & 420 & 100 & & Toplam & 420 & 100 \\
\hline \multirow{5}{*}{ Yaş } & $15-24$ & 89 & 212 & \multirow{5}{*}{$\begin{array}{l}\text { Eğitim } \\
\text { Durumu }\end{array}$} & İlköğretim & 56 & 13,3 \\
\hline & $1 J-24$ & 07 & 21,2 & & Lise & 199 & 47,4 \\
\hline & $25-60$ & 232 & 55,2 & & Lisans & 147 & 35,0 \\
\hline & 60 ve üzeri & 99 & 23,6 & & Lisans üstü & 18 & 4,3 \\
\hline & Toplam & 420 & 100 & & Toplam & 420 & 100 \\
\hline \multirow{8}{*}{ Meslek } & İşçi & 48 & 11,4 & \multirow{8}{*}{$\begin{array}{l}\text { Gelir } \\
\text { Durumu }\end{array}$} & $1000 \mathrm{TL}$ ve altı & 101 & 24,0 \\
\hline & Memur & 66 & 15,7 & & 1001-1999 & 53 & 12,6 \\
\hline & Emekli & 75 & 17,9 & & 2000-2999 & 119 & 28,3 \\
\hline & Esnaf & 51 & 12,1 & & \multirow{2}{*}{$3000-4999$} & \multirow{2}{*}{120} & \multirow{2}{*}{28,6} \\
\hline & Ev Hanımı & 23 & 5,5 & & & & \\
\hline & Öğrenci & 57 & 13,6 & & \multirow{2}{*}{5000 TL ve üzeri } & \multirow{2}{*}{27} & \multirow{2}{*}{6,4} \\
\hline & Diğer & 100 & 23,8 & & & & \\
\hline & Toplam & 420 & 100 & & Toplam & 420 & 100 \\
\hline
\end{tabular}

Tablo 2 incelendiğinde araştırmaya katılan bireylerin \%38,3'ünün kadın, \%61,7'sinin erkek olduğu görülmektedir. Katılımcıların \%58,1'i evli, \%41,9'u ise bekârdır. Katılımcıların çoğunluğu (\%55,2) 25-60 yaş aralığındadır. Katılımcıların eğitim durumlarına bakıldığında, katılımcıların çoğunluğunun $(\% 47,4)$ lise mezunu olduğu görülmektedir. Katılımcıların meslekleri incelendiğinde, kat1lımcıların \%11,4'ünün işçi, \%15,7'sinin memur, \%17,9'unun emekli, \%12,1'inin esnaf, \%5,5'inin ev hanımı, \%13,6'sının öğrenci olduğu, katılımcıların \%23,8'inin ise diğer mesleklerle ilgilendiği tespit edilmiştir. Katılımcıların gelir durumları incelendiğinde ise; \%24'ünün 1.000 TL ve alt1, \%12,6'sının 1.001 ile 1.999 TL aras1, \%28,3'ünün 2.000 ile 2.999 TL arası, \%28,6'sinın 3.000 ile 4.999 TL arası ve \%6,4'ünün 5.000 TL ve üzeri gelir durumuna sahip olduğu görülmektedir.

\section{Faktör Analizleri}

Müşteri deneyimi, müşteri memnuniyeti ve müşteri sadakatinin kaç alt boyutta algılandığını bulabilmek için faktör analizi yapılmıştır. Faktör analizi temel bileşenler ve varimax rotasyonu yöntemi ile güvenirlik analizi Cronbach's Alpha katsayısı ile yapılmıştır. Verilerin faktör analizine uygun olup olmadığı KMO ve Barlett testleri ile ölçülmüştür.

Her üç ölçeğe uygulanan faktör analizi kapsamında, Kaiser-Meyer-Olkin (Müşteri Deneyimi $\mathrm{KMO}=0,939$; Müşteri Memnuniyeti $\mathrm{KMO}=0,879$; Müşteri Sadakati $\mathrm{KMO}=0,868$ ) ile bütün soru grubunun genel olarak faktör analizine uygunluğu ölçülmüştür. Ayrıca tek tek her bir sorunun faktör analizine uygunluğu da ölçülmüsştür. Bu ölçüm esnasında Measures of Sampling AdequacyÖrnekleme Yeterliliğinin Ölçümü (MSA) yöntemi kullanılarak değişkenlerin anti-image korelasyon matrisi gözden geçirilmiştir. Anti-image korelasyon matrisindeki MSA değerleri incelendiğinde tüm değişkenlerin 0,50 değerinin üzerinde olduğu tespit edilmiştir.

Ölçeğin içerik geçerliliği, kuramsal bilgiler doğrultusunda gözlenen değişkenler, uzman görüşü, dil, imla ve anlatım (ifade) kontrolü sonrası oluşmuştur. Yapısal geçerliliği sağlamak için ise gerçekleştirilen faktör analizi doğrultusunda, her bir gözlenen değişkenin faktör yüklerinin diğer 
Deneyim Boyutlarının Müşteri Memnuniyet ve Sadakatine Etkisi: Konya Şehir Merkezinde... 827

faktör yüklerinden önemli düzeyde ayrıştığı gözlemlenmiş ve faktör yükü ,40 üstü olanlar analize dahil edilmiş̧ir.

Tablo 3: Müşteri Deneyimi Faktör Yapıs

\begin{tabular}{|c|c|c|c|c|c|c|c|c|c|c|}
\hline \multirow{2}{*}{ Faktör } & \multirow{2}{*}{$\begin{array}{c}\text { Değişkenle } \\
\mathrm{r}\end{array}$} & \multicolumn{8}{|c|}{ Faktör Yapıs1 } & \multirow{2}{*}{$\begin{array}{c}\text { Cronbach's } \\
\text { Alpha }\end{array}$} \\
\hline & & 1 & 2 & 3 & 4 & 5 & 6 & 7 & 8 & \\
\hline \multirow{10}{*}{ 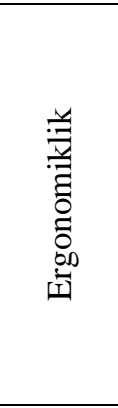 } & s23 & ,786 & & & & & & & & \multirow{10}{*}{,934 } \\
\hline & s22 & ,783 & & & & & & & & \\
\hline & s26 & ,764 & & & & & & & & \\
\hline & s24 & ,741 & & & & & & & & \\
\hline & s27 & 731 & & & & & & & & \\
\hline & s29 & ,715 & & & & & & & & \\
\hline & s25 & ,714 & & & & & & & & \\
\hline & s28 & ,701 & & & & & & & & \\
\hline & s30 & 696 & & & & & & & & \\
\hline & s31 & 452 & & & & & & & & \\
\hline \multirow{9}{*}{ 吉 } & s51 & & ,754 & & & & & & & \multirow{9}{*}{,910 } \\
\hline & s49 & & ,732 & & & & & & & \\
\hline & s47 & & ,728 & & & & & & & \\
\hline & s50 & & ,723 & & & & & & & \\
\hline & s52 & & ,716 & & & & & & & \\
\hline & s48 & & ,708 & & & & & & & \\
\hline & s46 & & 669 & & & & & & & \\
\hline & s45 & & 625 & & & & & & & \\
\hline & s44 & & ,469 & & & & & & & \\
\hline \multirow{9}{*}{ 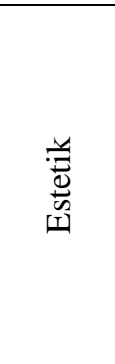 } & s7 & & & ,717 & & & & & & \multirow{9}{*}{,917 } \\
\hline & s4 & & & ,708 & & & & & & \\
\hline & s3 & & & ,707 & & & & & & \\
\hline & s5 & & & 690 & & & & & & \\
\hline & s2 & & & 662 & & & & & & \\
\hline & s6 & & & 654 & & & & & & \\
\hline & s1 & & & 650 & & & & & & \\
\hline & s8 & & & ,599 & & & & & & \\
\hline & s9 & & &, 569 & & & & & & \\
\hline \multirow{5}{*}{$\begin{array}{l}\frac{8}{0} \\
\frac{0}{100} \\
11\end{array}$} & s15 & & & & 745 & & & & & \multirow{5}{*}{,853 } \\
\hline & s14 & & & & 726 & & & & & \\
\hline & s13 & & & & 709 & & & & & \\
\hline & s16 & & & & 689 & & & & & \\
\hline & $\mathrm{s} 12$ & & & & ,598 & & & & & \\
\hline \multirow{5}{*}{ 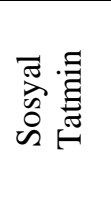 } & s41 & & & & & 742 & & & & \multirow{5}{*}{,872 } \\
\hline & s40 & & & & & .738 & & & & \\
\hline & $\mathrm{s} 42$ & & & & & 693 & & & & \\
\hline & s43 & & & & & 668 & & & & \\
\hline & s39 & & & & & 600 & & & & \\
\hline
\end{tabular}


Tablo 3: Müșteri Deneyimi Faktör Yapısı (Devam)

\begin{tabular}{|c|c|c|c|c|c|c|c|c|c|c|}
\hline \multirow{2}{*}{ Faktör } & \multirow{2}{*}{ Değişkenler } & \multicolumn{8}{|c|}{ Faktör Yapıs1 } & \multirow{2}{*}{$\begin{array}{c}\text { Cronbach's } \\
\text { Alpha }\end{array}$} \\
\hline & & 1 & 2 & 3 & 4 & 5 & 6 & 7 & 8 & \\
\hline \multirow{4}{*}{ 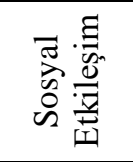 } & s36 & & & & & & ,734 & & & \multirow{4}{*}{, 882} \\
\hline & s37 & & & & & & 687 & & & \\
\hline & s35 & & & & & & ,636 & & & \\
\hline & $\mathrm{s} 38$ & & & & & & ,631 & & & \\
\hline \multirow{4}{*}{ 离 } & s18 & & & & & & & ,654 & & \multirow{4}{*}{, 826} \\
\hline & s19 & & & & & & & 591 & & \\
\hline & s20 & & & & & & & ,494 & & \\
\hline & s17 & & & & & & &, 459 & & \\
\hline \multirow{3}{*}{$\begin{array}{l}\text { 窇 } \\
\text { 恶 }\end{array}$} & s33 & & & & & & & & ,756 & \multirow{3}{*}{,894 } \\
\hline & s32 & & & & & & & & ,722 & \\
\hline & s34 & & & & & & & & ,702 & \\
\hline \multicolumn{2}{|l|}{ Özdeğer } & 18,031 & 7,185 & 2,762 & 2,154 & 1,616 & 1,372 & 1,349 & 1,182 & \\
\hline \multicolumn{2}{|c|}{ Açıklanan Varyans } & 13,942 & 11,424 & 10,767 & 7,209 & 6,633 & 5,370 & 4,834 & 4,471 & \\
\hline \multicolumn{2}{|c|}{$\begin{array}{l}\text { Toplam Açılanan } \\
\text { Varyans }\end{array}$} & 64,649 & & & & & & & & \\
\hline \multicolumn{2}{|c|}{ KMO } & ,939 & & & & & & & & \\
\hline \multicolumn{2}{|c|}{ Barlett } & 16897,2 & 9 (sd. 14 & $31 ; p=0$ & 000) & & & & & \\
\hline \multicolumn{2}{|c|}{ Cronbach's Alpha } & ,959 & & & & & & & & \\
\hline
\end{tabular}

Müşteri Deneyimi ölçeğinin faktör analizi sonucunda bazı faktör ağırlıklarının (10-11-2153-54. maddeler) birden fazla faktör altında yakın değerler aldığı tespit edilmiş̧ir. Herhangi bir sorunun farklı faktör sütunlarında yakın değerler alması söz konusu ise maddenin analiz dış1 bırakılması gerekmektedir (Durmuş, Yurtkoru, Çinko, 2013: 85). Bu doğrultuda, 10, 11, 21, 53 ve 54. maddelerin birden fazla faktör altında birbirine yakın değerler aldığı görüldüğü için bu sorular sırasıyla analiz dışı bırakılarak faktör analizi tekrar yapılmıştır. Yapılan faktör analizi sonucunda birden fazla faktör altında birbirine yakın faktör ağırlığına sahip başka bir maddeye rastlanmadığ 1 için analize bu şekliyle devam edilmiştir. Faktör analizine göre, müşteri deneyimi ölçeği katılımcılarca sekiz alt boyutta algılanmıştır. Bu boyutlara ait basıklık-çarpıklık değerlerine bakıldığında, normal dağılım gösterdikleri sonucuna ulaşılmıştır (Tablo 4). \pm 1.5 arasında bir basıklık ve çarpıklık değeri çoğu psikometrik amaç için mükemmel kabul edilir, ancak belirli bir uygulamaya bağlı olarak \pm 2.0 arasında bir değer de kabul edilebilir (George \& Mallery 2010; Hair, Black, Babin \& Anderson, 2013).

Tablo 4: Müşteri Deneyimi Alt Faktörleri Basıklık Çarpıklık Değerleri

\begin{tabular}{lrrrr}
\hline \multirow{2}{*}{ Alt Boyutlar } & \multicolumn{2}{c}{ Skewness (Çarpıklık) } & \multicolumn{2}{c}{ Kurtosis (Basıklık) } \\
\cline { 2 - 5 } & Değer & Std. Sapma & Değer & \multicolumn{1}{c}{ Std. Sapma } \\
\hline Verimlilik & $-1,074$ &, 119 &, 725 &, 238 \\
Ekonomiklik Mükemmellik &, 147 &, 119 &,- 375 &, 238 \\
\hline Eğitim &,- 903 &, 119 &, 454 &, 238 \\
\hline Estetik &, 188 &, 119 &,- 516 &, 238 \\
\hline Ĕglence &,- 121 &, 119 &, 009 &, 238 \\
\hline Sosyal Tatmin &,- 768 &, 119 &, 411 &, 238 \\
\hline Sosyal Etkileşim &,- 489 &, 119 &,- 068 &, 238 \\
\hline KaçıŞ &, 321 &, 119 &,- 711 &, 238 \\
\hline Alturistik & & & &
\end{tabular}


Sekiz alt boyut, ölçeğin toplam varyansının \%64,649'unu açıklamıştır. Elde edilen her bir faktörün kendi içerisindeki uyumu Cronbach's Alpha katsayısı ile ölçülmüştür. Bu katsayı sorular arası korelasyona bağlı uyum değeridir. Müşteri deneyimi ölçeğinin tüm alt boyutlarında Cronbach's Alpha değerleri \%60'ın üstünde yer aldığ 1 için faktörlerin istatistiksel olarak güvenilir olduğu sonucuna ulaşılmıştır. Ölçeğin yapısal geçerliliğini sağlamak üzere, her bir gözlenen değişkenin faktör yüklerinin diğer faktör yüklerinden önemli düzeyde ayrıştığı gözlemlenmiş ve faktör yükü ,40 üstü olanlar analize dahil edilmiştir.

Tablo 5: Müșteri Memnuniyeti Faktör Yapısı

\begin{tabular}{|c|c|c|c|}
\hline \multirow{2}{*}{ Faktör } & \multirow{2}{*}{ Değişkenler } & Faktör Yapısı & \multirow{2}{*}{ Cronbach's Alpha } \\
\hline & & 1 & \\
\hline \multirow{6}{*}{ 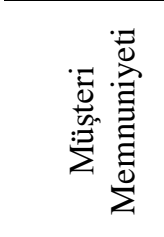 } & s59 & ,842 & \multirow{6}{*}{,909 } \\
\hline & s56 & 840 & \\
\hline & s58 & 840 & \\
\hline & s60 &, 830 & \\
\hline & s57 & 827 & \\
\hline & s55 & ,795 & \\
\hline Özdeğer & & 4,125 & \\
\hline \multicolumn{2}{|c|}{ Açıklanan Varyans } & 68,745 & \\
\hline \multicolumn{2}{|c|}{ Toplam Açıklanan Varyans } & 68,745 & \\
\hline \multicolumn{2}{|c|}{ KMO } &, 879 & \\
\hline \multicolumn{2}{|l|}{ Barlett } & 1558,134 (sd. $15 ; \mathrm{p}=0$ & \\
\hline
\end{tabular}

Faktör analizine göre müşteri deneyimi ölçeği katılımcılarca tek boyutta algılanmıştır. $\mathrm{Bu}$ boyut ölçeğin toplam varyansının \%68,745'ini açıklamıştır. Müşteri memnuniyeti faktörünün kendi içerisindeki uyumu Cronbach's Alpha katsayısı ile ölçülmüştür. Bu katsayı sorular arası korelasyona bağlı uyum değeridir. Müşteri memnuniyeti ölçeğinin Cronbach's Alpha değeri \%60'ın üzerinde olduğu için faktörün istatistiksel olarak güvenilir olduğu sonucuna ulaşılmıştır. Ölçeğin yapısal geçerliliğini sağlamak üzere, her bir gözlenen değişkenin faktör yüklerinin diğer faktör yüklerinden önemli düzeyde ayrıştı̆̆ gözlemlenmiş ve faktör yükü ,40 üstü olanlar analize dahil edilmiştir.

Tablo 6: Müșteri Sadakati Faktör Yapısı

\begin{tabular}{|c|c|c|c|}
\hline \multirow{2}{*}{ Faktör } & \multirow{2}{*}{ Değişkenler } & Faktör Yapısı & \multirow{2}{*}{$\begin{array}{c}\text { Cronbach's } \\
\text { Alpha }\end{array}$} \\
\hline & & 1 & \\
\hline \multirow{5}{*}{ 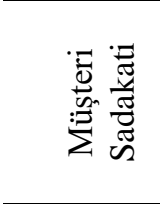 } & s63 & ,875 & \multirow{5}{*}{,905 } \\
\hline & s64 & ,867 & \\
\hline & s62 &, 856 & \\
\hline & s65 & ,838 & \\
\hline & s61 &, 825 & \\
\hline \multicolumn{2}{|l|}{ Özdeğer } & 3,631 & \\
\hline \multicolumn{2}{|c|}{ Açıklanan Varyans } & 72,628 & \\
\hline \multicolumn{2}{|c|}{ Toplam Açıklanan Varyans } & 72,628 & \\
\hline \multicolumn{2}{|l|}{ KMO } & ,868 & \\
\hline \multicolumn{2}{|l|}{ Barlett } & $1322,436$ (sd.10; $\mathrm{p}=0,000)$ & \\
\hline
\end{tabular}

Faktör analizine göre müşteri deneyimi ölçeği katılımcılarca tek boyutta algılanmıştır. $\mathrm{Bu}$ boyut ölçeğin toplam varyansının \%72,628'ini açıklamıştır. Müşteri sadakati faktörünün kendi 
içerisindeki uyumu Cronbach's Alpha katsayısı ile ölçülmüştür. Bu katsayı sorular arası korelasyona bağlı uyum değeridir. Müşteri memnuniyeti ölçeğinin Cronbach's Alpha değeri \%60'ın üzerinde olduğu için faktörün istatistiksel olarak güvenilir olduğu sonucuna ulaşılmıştır.

\section{Hipotezlerin Testi}

Araştırma modeli doğrultusunda kurulan hipotezleri test etmek için korelasyon analizi ve çoklu doğrusal regresyon analizi gerçekleştirilmiştir.

Tablo 7: Müşteri Deneyimi Alt Boyutları ile Müşteri Memnuniyeti ve Müşteri Sadakati İlişkisi Korelasyon Analizi

\begin{tabular}{|c|c|c|c|c|c|c|c|c|c|c|c|}
\hline \multicolumn{12}{|c|}{ Müşteri Deneyimi Boyutu } \\
\hline & & $\mathrm{Er}$ & E & Es & $E \breve{g}$ & ST & SE & K & A & MM & $\mathrm{MS}$ \\
\hline \multirow{10}{*}{ 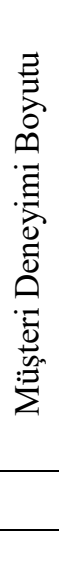 } & $\mathrm{Er}$ & 1 & & & & & & & & & \\
\hline & E &, $246^{* *}$ & 1 & & & & & & & & \\
\hline & Es &, $733^{* *}$ & $264^{* *}$ & 1 & & & & & & & \\
\hline & $\overline{E g}$ & ,348** & $497^{* *}$ & $313^{* *}$ & 1 & & & & & & \\
\hline & ST &, $355^{* *}$ &, $666^{* *}$ &, $385^{* *}$ & $390^{* *}$ & 1 & & & & & \\
\hline & SE & ,632** & $374^{* *}$ &, $592^{* *}$ & $309^{* *}$ & $467^{* * *}$ & 1 & & & & \\
\hline & K & ,632** &, $365^{* *}$ &, $595^{* *}$ &, $512^{* *}$ &, $357^{* *}$ &, $534^{* *}$ & 1 & & & \\
\hline & A & $187^{* *}$ &, $672^{* * *}$ & $179^{* *}$ & $483^{* *}$ &, $528^{* *}$ &, $338^{* *}$ & $267^{* *}$ & 1 & & \\
\hline & MM & $296^{* *}$ & ,704 $4^{* * *}$ & $306^{* *}$ & $420^{* *}$ &, $588^{* *}$ & ,388** &, $384^{* *}$ & $603^{* *}$ & 1 & \\
\hline & MS &, $272^{* *}$ &, $627^{* * *}$ &, $276^{* *}$ &, $385^{* *}$ &, $531^{* *}$ &, $388^{* *}$ &, $336^{* *}$ &, $515^{* *}$ &, $809^{* *}$ & 1 \\
\hline
\end{tabular}

** Korelasyon 0.01 düzeyinde anlamlıdır. $\mathrm{n}=420$.

Ergonomiklik (Er), E (Eğitim), Es (Estetik), Ĕg (Eğlence), ST (Sosyal Tatmin), SE (Sosyal Etkileşim),

K (Kaçış), A (Alturistik); MM (Müşteri Memnuniyeti), MS (Müşteri Sadakati) anlamındadır.

Tablo 7 incelendiğinde; müşteri deneyimi, müşteri memnuniyeti ve müşteri sadakati arasında anlamlı ilişkiler tespit edilmiştir. 
Deneyim Boyutlarının Müşteri Memnuniyet ve Sadakatine Etkisi: Konya Şehir Merkezinde... 831

Tablo 8: Müssteri Deneyimi Alt Boyutları ile Müssteri Memnuniyeti İlişkisi Regresyon Katsayıları

\begin{tabular}{|c|c|c|c|c|c|}
\hline $\begin{array}{l}\text { Bağımlı } \\
\text { Değişken }\end{array}$ & $\begin{array}{l}\text { Bağımsız } \\
\text { Değişkenler }\end{array}$ & $\begin{array}{c}\text { Standardize } \\
\text { Katsayilar }\end{array}$ & $\begin{array}{c}\mathrm{t}- \\
\text { istatistiği }\end{array}$ & $\mathrm{p}$ değeri & $\begin{array}{c}\text { Standart } \\
\text { Hata }\end{array}$ \\
\hline \multirow{11}{*}{$\begin{array}{l}\text { Müşteri } \\
\text { Memnuniyeti }\end{array}$} & Ergonomiklik & ,014 & ,264 & ,792 & ,157 \\
\hline & Eğitim & ,421 & 8,033 &, 000 &, 053 \\
\hline & Estetik & ,029 &, 564 &, 573 &, 057 \\
\hline & Eğlence &,- 016 &,- 379 & ,705 &, 052 \\
\hline & Sosyal Tatmin &, 143 & 3,018 &, 003 &, 044 \\
\hline & Sosyal Etkileşim & ,020 & ,432 & ,666 & ,049 \\
\hline & Kaçış & ,094 & 1,951 &, 052 &, 046 \\
\hline & Alturistik & ,214 & 4,590 & ,000 & ,049 \\
\hline & $\mathrm{R}^{2}$ & ,559 & & & \\
\hline & Düzeltilmiş $\mathrm{R}^{2}$ &, 551 & & & \\
\hline & $\mathrm{F}$ istatistĭği & $65,211(\mathrm{p}=0,000)$ & & & \\
\hline
\end{tabular}

Tablo 8 incelendiğinde, müşteri deneyimi alt boyutlarından sadece "eğitim", "sosyal tatmin" ve "alturistik" değişkenlerinin müşteri memnuniyeti değişkenini istatistiksel olarak anlamlı düzeyde $(\mathrm{p}<0,05)$ etkilediği tespit edilmiştir. Diğer bir ifadeyle, "müşteri memnuniyeti” değişkenini "müşteri deneyimi" ölçeğinin üç alt boyutundan ("eğitim", "sosyal tatmin" ve "alturistik") en az biri ile tahmin etmek istatistiksel olarak mümkündür. Müşteri deneyiminin diğer alt boyutlarının, müşteri memnuniyeti üzerinde istatistiksel olarak anlamlı bir etkisi bulunmamıştır. Ayrıca VIF değerlerinin 5 değerinden küçük olması değişkenler arasında çoklu bağıntı olmadığını göstermektedir. Tablodaki $\mathrm{R}^{2}$ ve düzeltilmiş $\mathrm{R}^{2}$ değerleri modelin açıklama gücünü göstermektedir. Yapılan regresyon analizi sonucunda bağımsız değişkenlerin müşteri memnuniyeti değişkenini açıklama oranı $\% 55,9$ olarak bulunmuştur. Ayrıca katsayılar tablosu incelendiğinde bu açıklayıcılığa en büyük katkıyı-etkiyi "eğitim" değişkeninin sağladığı görülmektedir.

Müșteri Deneyimi ile Müşteri Memnuniyeti arasındaki test sonuçlarına göre; eğitim, sosyal tatmin ve alturistik boyutlarının müşteri memnuniyeti üzerinde istatistiksel olarak anlamlı etkisi vardır. H1b, H1e, H1h kabul edilmiştir. Diğer boyutların müşteri memnuniyeti üzerinde istatistiksel olarak anlamlı bir etkisi yoktur. H1a, H1c, H1d, H1f, H1g reddedilmiştir. 
Tablo 9: Müssteri Deneyimi Alt Boyutları ile Müşteri Sadakati İlişkisi Regresyon Katsayıları

\begin{tabular}{|c|c|c|c|c|c|}
\hline $\begin{array}{c}\text { Bağımlı } \\
\text { Değişken }\end{array}$ & $\begin{array}{c}\text { Bağımsız } \\
\text { Değişkenler }\end{array}$ & $\begin{array}{c}\text { Standardize Katsayılar } \\
\text { Beta }\end{array}$ & t-istatistiği & p değeri & $\begin{array}{c}\text { Standart } \\
\text { Hata }\end{array}$ \\
\hline \multirow{11}{*}{$\begin{array}{l}\text { Müşteri } \\
\text { Sadakati }\end{array}$} & $\begin{array}{l}\text { Ergonomiklik } \\
\text { (VEM) }\end{array}$ & ,001 & ,018 & ,985 &, 062 \\
\hline & Eğitim &, 385 & 6,544 & ,000 & ,067 \\
\hline & Estetik & ,006 & ,105 & ,917 & ,061 \\
\hline & Eğlence &, 025 &, 516 & ,606 & ,051 \\
\hline & Sosyal Tatmin & ,131 & 2,468 &, 014 & ,057 \\
\hline & Sosyal Etkileşim & ,106 & 2,012 & ,045 &, 054 \\
\hline & Kaçış & ,041 &, 750 & , 453 & ,057 \\
\hline & Alturistik & ,127 & 2,427 & ,016 &, 046 \\
\hline & \multicolumn{4}{|c|}{$\mathrm{R}^{2} \quad, 443$} & \\
\hline & Düzeltilmiş $\mathrm{R}^{2}$ & ,432 & & & \\
\hline & $\mathrm{F}$ istatistiği & $40,844(\mathrm{p}=0,000)$ & & & \\
\hline
\end{tabular}

Tablo 9 incelendiğinde, müssteri deneyimi alt boyutlarından sadece "eğitim", "sosyal tatmin", "sosyal etkileşim" ve "alturistik" değişkenlerinin müşteri sadakati değişkenini istatistiksel olarak anlamlı düzeyde $(\mathrm{p}<0,05)$ etkilediği tespit edilmiştir. Müşteri deneyimi diğer alt boyutlarının, müşteri sadakati üzerinde istatistiksel olarak anlamlı bir etkisi bulunmamıştır. Diğer bir ifadeyle, "müşteri sadakati” değişkenini "müşteri deneyimi” ölçeğinin dört alt boyutundan ("eğitim", "sosyal tatmin", "sosyal etkileşim" ve "alturistik") en az biri ile tahmin etmek istatistiksel olarak mümkündür. Tabloya göre tüm değişkenler için $p$ değerleri 0,05 'ten küçük olduğundan müşteri deneyimi alt değişkenleri, müşteri sadakati değişkenini açıklamakta istatistiksel olarak anlamlıdır. Ayrıca VIF değerlerinin 5 değerinden küçük olması değişkenler arasında çoklu bağıntı olmadığını göstermektedir. Tablodaki $\mathrm{R}^{2}$ ve düzeltilmiş $\mathrm{R}^{2}$ değerleri modelin açıklama gücünü göstermektedir. Yapılan regresyon analizi sonucunda bağımsız değişkenlerin müşteri sadakati değişkenini açıklama oranı \% 44,3 olarak bulunmuştur. Ayrıca katsayılar tablosu incelendiğinde bu açılayıcıllğa en büyük katkıy1-etkiyi "eğitim” değişkeninin sağladığı görülmektedir.

Müşteri Deneyimi ile Müş̧eri Sadakati arasındaki test sonuçlarına göre; eğitim, sosyal tatmin, sosyal etkileşim ve alturistik boyutlarının müşteri sadakati üzerinde istatistiksel olarak anlamlı etkisi vardır. H2b, H2e, H2f, H2h kabul edilmiştir. Diğer boyutların müssteri sadakati üzerinde istatistiksel olarak anlamlı bir etkisi yoktur. $\mathrm{H} 2 \mathrm{a}, \mathrm{H} 2 \mathrm{c}, \mathrm{H} 2 \mathrm{~d}, \mathrm{H} 2 \mathrm{e}, \mathrm{H} 2 \mathrm{~g}$ reddedilmiştir.

\section{Sonuç}

Tüm sektörlerde olduğu gibi turizm sektöründe de pazar yapıları devamlı gelişmekte, tüketici istek ve talepleri değişmekte ve rekabet gün geçtikçe artmaktadır. Bu durum, işletme yöneticileri ve pazarlamacılarını rekabet üstünlüğünü ve büyümeyi sağlayarak kârlılığı artıracak farklı ve yenilikçi stratejiler geliştirmeye zorlamaktadır. Bu stratejiler geliştirilirken müşteri deneyimleri ve değerleri göz ardı edilmemelidir. Bu amaçla müşteri sadakati oluşturmada ve işletme kârlılığını artırmada müşteri ilişkilerine öncelik verilerek fark yaratan ve talep gören müşteri deneyimleri oluşturulmaya çalışılmaktadır. Turistik davranışlara daha çok, deneyim türleri, deneyim boyutları ve deneyim sağlayıcılar etki etmektedir. Örneğin, hayaller, duygular, arzular ve fanteziler turizm deneyimlerini 
önemli ölçüde etkilemektedir. Bu nedenle turizm sektöründe tüketiciye sunulan ürünler tüketiciyi heyecanlandırmalı ve tüketiciye düşlerini ve hayallerini gerçekleştirmiş olma duygusunu tattırabilmelidir. Bu stratejiler geliştirilirken müşteri deneyimleri ve değerleri göz ardı edilmemelidir. Yapılan araştırma müşteri deneyimi ile müşteri memnuniyeti ve müşteri sadakati arasında anlamlı ilişkiler olduğunu ortaya koymuştur.

Araştırmanın amacı kapsamında yer alan müşteri deneyim boyutları, müşteri memnuniyeti ve müşteri sadakati arasındaki ilişkiyi tespit edebilmek için faktörler arasında korelasyon ve regresyon ilişkisi incelenmiştir. Müşteri memnuniyeti ve müşteri sadakati ölçeği bağımlı değişkeni ile müşteri deneyim boyutları bağımsız değişkenleri arasında anlamlı ilişkiler tespit edilmiştir.

Öncelikle müşteri deneyim alt boyutları ile müşteri memnuniyeti arasındaki ilişkiye bakmak için regresyon analizi yapıldığında bu boyutlardan sadece eğitim, sosyal tatmin ve alturistik (işletme faliyetlerinde çevre duyarlılığını gözetme) değişkenlerinin istatistiksel olarak müşteri memnuniyeti değişkenini anlamlı yönde etkilediği sonuçlarına ulaşılmıştır. Yapılan regresyon analizi sonucunda bağımsız değişkenlerin müşteri memnuniyeti değişkenini açıklama oranı yüzde 54,5 olarak tespit edilmiştir. Bu açıklayıcılığa etki sıralaması ise eğitim, alturistik, sosyal tatmin şeklindedir.

Turizm sektöründe pazar yapıları devamlı gelişmekte, tüketici istek ve talepleri değişmekte ve rekabet gün geçtikçe artmaktadır. Bu durum, işletme yöneticilerini ve pazarlama sorumlularını rekabet üstünlüğünü ve büyümeyi sağlayarak kârlılı̆̆ 1 arttıracak farklı ve yenilikçi stratejiler geliştirmeye zorlamaktadır. Bu stratejiler geliştirilirken müşteri deneyimleri ve değerleri göz ardı edilmemelidir. Yapılan araştırma, müşteri deneyimi ile müşteri memnuniyeti ve müşteri sadakati arasında anlamlı ilişkiler olduğunu ortaya koymuştur.

Araştırmada, konaklama işletmelerinde müşteri deneyimini etkileyen faktörler; ergonomiklik, eğitim, estetik, eğlence, sosyal tatmin, sosyal etkileşim, kaçış ve alturistik olarak belirlenmiştir.

Araştırmanın ilk hipotezi, H1: "Müşteri deneyiminin ergonomiklik (a), eğitim (b), estetik (c), eğlence (d), sosyal tatmin (e), sosyal etkileşim (f), kaçış (g), alturistik (h) boyutunun müşteri memnuniyeti üzerinde anlamlı etkisi vardır." olarak belirlenmiştir. Müşteri deneyimi ile müşteri memnuniyeti arasındaki ilişki incelendiğinde, sırasıyla deneyimin eğitim, sosyal tatmin ve alturistik boyutlarının müşteri memnuniyetini olumlu yönde etkilediği sonucuna ulaşılmıştır. Diğer bir ifadeyle, müşterilerin konaklama işletmelerindeki eğitim, sosyal tatmin ve alturistik deneyimleri, müşteri memnuniyetini olumlu yönde etkilemektedir. Müşterilerin, konaklama işletmelerinde eğitim alanındaki faaliyetlere katılarak sahip oldukları becerileri geliştirme ya da yeni beceriler kazanma (eğitim), öz saygı, tanınma ve sosyal imajlarını güçlendirme (sosyal tatmin), kendilerine ve çevrelerine değer katma (alturistik) deneyimlerinin, memnuniyetlerinin ardındaki temel faktörlerdir. $\mathrm{Bu}$ sonuçlara bakıldığında, H1 hipotezinin, deneyimin eğitim (b), sosyal tatmin (e) ve alturistik (h) boyutlarının müşteri memnuniyeti üzerinde etkili olduğu kabul edilmiştir.

Araştırmanın ikinci hipotezi, H2: "Müşteri deneyiminin ergonomiklik (a), eğitim (b), estetik (c), eğlence (d), sosyal tatmin (e), sosyal etkileşim (f), kaçış (g), alturistik (h) boyutunun müşteri sadakati üzerinde anlamlı etkisi vardır." olarak belirlenmiştir. Müşteri deneyim alt boyutları ile müşteri sadakati arasındaki ilişki incelendiğinde; eğitim, sosyal tatmin, sosyal etkileşim ve alturistik boyutlarının müşteri sadakatini olumlu yönde etkilediği sonucuna ulaşılmıştır. Aynı zamanda müşteri memnuniyetini de sağlayan eğitim, sosyal tatmin ve alturistik deneyim faktörlerine ek olarak, müşterilerin konaklama süresince aynı işletmede bulunduğu diğer müşteriler ve çalışanlarla etkileşim deneyimi (sosyal etkileşim), müşteri sadakatini sağlayan bir faktör olarak ortaya çıkmıştır. Bu sonuçlara bakıldığında, H2 hipotezinin, deneyimin eğitim (b), sosyal tatmin (e), sosyal etkileşim (f) ve alturistik (h) boyutlarının müşteri sadakati üzerinde etkili olduğu kabul edilmiştir. Bu sonuçlar, Holbrook'un (1994 ve 2005), Schmitt'in (1999) ve Brady ve Cronin'in (2001) araştırma sonuçlariyla uyum göstermektedir. 
Araştırma sonuçları müşteri memnuniyeti ve müşteri sadakatine en büyük katkıyı eğitim deneyiminin sağladığı göstermektedir. Ayrıca, eğitim, alturistik ve sosyal tatmin deneyimlerinin gerek müşseri memnuniyeti gerekse müş̧eri sadakati üzerinde etkili olduğunu görülmüştür. $\mathrm{Bu}$ açıdan, araştırma kapsamındaki konaklama işletmelerinde özellikle bu deneyim boyutlarına yönelik etkinliklerin iyileştirilmesi, işletmelerin yüksek müşteri memnuniyeti ve sadakati sağlayarak kârlılıklarının artmasına katkı sağlayabilir. Dolayısıyla, konaklama işletmeleri, müşterilerin merak duygularını uyandıran, öğrenme içgüdülerini harekete geçiren eğitici ve öğretici aktiviteler düzenleyerek "eğitim"; çevreye duyarlı mal ve hizmetler sunarak "alturistik", müşterilerle öz saygılarını artıracak ilişkiler kurarak "sosyal tatmin" ve müşteriler arası iletişim sağlayarak "sosyal etkileşim" deneyimlerini güçlendirmelidirler.

Her ne kadar diğer deneyim boyutlanı araştırma kapsamında müşteri memnuniyeti ve sadakati sağlamada etkili bulunmasa da müşterilerin her geçen gün değişen istek ve ihtiyaçları dikkate alınarak müşterilere zengin bir deneyim sağlamak önemlidir. Konaklama işletmeleri müşterilere farklı deneyimler sunmanın yanında, müşterilerin bu deneyimleri olabildiğince yoğun bir şekilde yaşamalarını da sağlamalıdırlar. Bu farklı deneyimlerin yaratılması aşamasında konaklama işletmelerinin yöneticileri görsel ve sözel kimlik, ürün tasarımı, iletişim gibi unsurlardan ve işletmedeki diğer çalışanlardan yararlanabilirler. Bu bağlamda, otellerde özellikle çalışan bütün personelin müşteri ilişkilerine önem vermesi, müşterilere sunulan vaatlerin zamanında yerine getirilmesi, mimari anlamda iç ve dış tasarıma önem verilmesi, otel imajına uygun mal ve hizmetlerin sunulması, sunulan mal ve hizmetlerde çevreye duyarlı olunması ve tutundurma çalışmalarında internetin ve elektronik iletişim araçlarının daha etkin ve yoğun olarak kullanılması faydalı olabilecektir.

$\mathrm{Bu}$ araştırmada bazı sınırlılıklar (kısıtlar) bulunmaktadır. Öncelikle, çalışmanın kapsamı 31 Aralık 2017 tarihi itibariyle Konya şehir merkezinde yer alan güncel turizm işletmesi belgeli 4 ve 5 yıldızlı konaklama işletmeleri ile sınırlı kalmaktadır. Bunun temel nedeni zaman ve maliyet kısıtlarıdır. Konya şehir merkezinde yer alan konaklama işletmelerinin çalışma alanı olarak seçilmesinin temel sebebi, bu işletmelerin yapı olarak şehir oteli olması ve yılın her günü hizmet vermeleridir. Bu doğrultuda elde edilen çalışma sonuçlarını farklı bir bölgeye, ülkenin tamamına ya da otel işletmelerinin tamamına genellemek doğru olmayacaktır. Ayrıca araştırma, ölçekte yer alan ifadeler ve katılımcıların sorulara verdikleri cevaplar ile sınırlı kalmaktadır. Katılımcıların verdikleri cevapların doğru olduğu varsayılmaktadır. Ölçeğin yapısı itibariyle kapalı uçlu sorulardan oluşması, açık uçlu sorulara yer verilmemesi, katılımcıların kendi görüşlerini bildirmelerini engellemektedir. Çalışmada, kapalı uçlu (yapılandırılmış) anket yönteminin kullanılması, çalışmanın sorunsalına hizmet eden en doğru yöntem olarak kabul edilmesindendir. Araştırma, müşteri deneyiminin sekiz boyutuyla sınırlandırılmıştır. Gelecekteki çalışmalarda, deneyim boyutları arttırılarak farklı sonuçlara ulaşılabilir. Örneklem 4 ve 5 yıldızlı otellerde konaklayan yerli müşterilerden oluşmuştur. Araştırmanın farklı şehirlerde ve statülerdeki otellerde, farklı etnik ve kültürel özelliklere sahip katılımcılara uygulanarak yapılması, turizm sektöründe deneyimsel pazarlama uygulamalarının etkinliğine katkı sağlayabilecek daha genel ve sağlıklı sonuçlar elde edilmesini sağlayacaktır. Nicel araştırmaların yanı sıra deneyimsel pazarlama uygulamalarına ağırlık veren turizm işletmelerinde gerçekleştirilecek nitel araştırmalar konunun derinlemesine incelenmesine katkı sağlayacaktır.

Elde edilen sonuçların deneyimsel pazarlama alanındaki literatüre katkı sağlaması beklenmektedir. Araştırma için seçilen deneyim boyutları artırılarak farklı sonuçlara ulaşılabilir. Araştırmanın farklı şehirlerde ve statülerdeki otellerde genişletilerek yapılması araştırma sonuçlarının güvenilirliğini destekleyecektir. Araştırma farklı etnik ve kültürel özelliklere sahip katılımcılara uygulanarak özellikle turizm sektöründe deneyimsel pazarlama uygulamalarının etkinliğine katk1 sağlayabilecek daha genel ve sağlıklı sonuçlar elde edilebilir. Nicel araştırmaların yanı sıra deneyimsel pazarlama uygulamalarına ağılık veren turizm işletmelerinde gerçekleştirilecek nitel araştırmalar konunun derinlemesine incelenmesine katkı sağlayacaktır. 
Deneyim Boyutlarının Müşteri Memnuniyet ve Sadakatine Etkisi: Konya Şehir Merkezinde... 835

\section{Kaynakça}

Artuğer, S., Çetinsöz B. Ç., Ercan F. \& Kendir H. (2014). Pazarlamada yeni yaklaşımlar ve turizmde uygulamaları, 1. Bask1, Ankara: Detay Yayınc1lık.

Aykaç, S. Ö. \& Kervenoael, R. D. (2008). Türkiye'de e-bankacılık: tüketici deneyimleri, 13. Ulusal Pazarlama Kongresi, 1-18.

Başar, B. (2015). Kültür ve sanat faaliyetlerinde deneyimsel pazarlamanın müssteri sadakatine etkisinin incelenmesi. Gazi Üniversitesi Sosyal Bilimler Enstitüsü Rekreasyon Yönetimi Anabilim Dalı Yüksek Lisans Tezi, Ankara.

Brady, M. \& Cronin J. (2001). Customer orientation: effects on customer service perceptions and outcome behaviors. Journal of Service Research, 3(3), 241-251. https://doi.org/10.1177/109467050133005

Çelik, A. (2013). Turizmde deneyimsel pazarlama: tur operatörlerine yönelik bir uygulama. Dokuz Eylül Üniversitesi Sosyal Bilimler Enstitüsü Turizm İşletmeciliği Anabilim Dalı Doktora Tezi, İstanbul.

Çeltek, E. (2010). Deneyimsel pazarlama unsurlarının pazarlama ile değerlendirilmesi: Türkiye'deki 4 ve 5 yıldızl otel işletmelerinde bir uygulama. Anadolu Üniversitesi Sosyal Bilimler Enstitüsü Turizm ve Otel İşletmeciliği Ana Bilim Dalı Doktora Tezi, Eskişehir.

Çiçek, B. (2015). Deneyimsel pazarlama ve satı alma karar sürecine etkisi: termal turizm sektöründe bir uygulama. Bozok Üniversitesi Sosyal Bilimler Enstitüsü İşletme Anabilim Dalı Yüksek Lisans Tezi, Yozgat.

Deligöz, K. (2016). Deneyimsel pazarlama. 1. Bask1, Ankara: Siyasal Kitapevi.

Durmuş, B., Yurtkoru E. S. \& Çinko M. (2013). Sosyal bilimlerde spss'le veri analizi. 5.Bask1, İstanbul: Beta Yayınları.

Erbaş, A. P. (2010). The effect of experiential marketing on customer satisfaction and loyalty: a study on Starbucks. Marmara Üniversitesi Sosyal Bilimler Enstitüsü İngilizce İșletme Anabilim Dalı Üretim Yönetimi ve Pazarlama (İngilizce) Bilim Dalı Yüksek Lisans Tezi, İstanbul.

George, D., \& Mallery, M. (2010). SPSS for Windows step by step: a simple guide and reference. 17.0 update (10a ed.) Boston: Pearson.

Güney, D. (2015). Deneyimsel pazarlamanın müssteri sadakatine etkisi: Muğla'daki butik otellere yönelik bir uygulama. Muğla Sttkı Koçman Üniversitesi Sosyal Bilimler Enstitüsü Turizm İşletmeciliği Ana Bilim Dalı Yüksek Lisans Tezi, Muğla.

Hair, J. F., Black, W. C., Babin, B. J., Anderson, R. E. \& Tatham, R. L. (2013). Multivariate data analysis: Pearson Education Limited.

Holbrook M. (2005). Customer value and autoetnography: subjective personal intropection and the meanings of a photograph collection. Journal of Business Research. 58(1), 45-61. https://doi.org/10.1016/s0148-2963(03)00079-1

Holbrook, M. (1994). The nature of customer value: an axiology of service in the consumption experience. Service Quality: New Direction in Theory and Practice. 21(1), 21-71. https://doi.org/10.4135/9781452229102.n2

Holbrook, M. (2006). Consumption experience, customer value, and subjective personal introspection: an 1llustrative photographic essay. Journal of Business Research. 59, 714-725. https://doi.org/10.1016/j.jbusres.2006.01.008 
Lin, K., M., Chang C.M., Lin Z. P., Tseng M. L., \& Lan L. W. (2006). An examination of the relationship between experiential marketing strategy and guests' leisure behavior in taiwan hot-spring hotels. Proques. 6(5), 229-240.

Oh, H., Fiore A. M. \& Jeoung M. (2007). Measuring experience economy concepts: tourism applications. Journal of Travel Research. 46(2) ,119-132. https://doi.org/10.1177/0047287507304039

Schmitt, Bernd (1999). Experiential marketing, New York: The Free Press.

Sharma, R. \& Sharma V. (2011). Experiential marketing: a comtemporary marketing mix. International Journal of Management and Strategy. (2) 3.

Smilansk, S. (2009). Experiential marketing_a practical guide to interactive brand experiences. London: Kogan Page.

Tabachnick B.G. \& Fidell L.S., (2013) Using multivariate statistics. (Sixth ed.)Pearson, Boston.

Tsai, S. P. (2005). Integrated marketing as management of holistic consumer experience. Business Horizons. 48(5), 431-441. https://doi.org/10.1016/j.bushor.2005.02.005

Tsaur, Sheng-Hshiung, Yi-Ti Chiu \& Chih-Hung Wang (2007). The visitors behavioral consequences of experiential marketing: an empirical study on Taipei Zoo, Journal of Travel \& Tourism Marketing. Vol 21, No 1, 47-64. https://doi.org/10.1300/j073v21n01_04

Williams, A. (2006), Tourism and hospitality marketing: fantasy, feeling and fun. International Journal of Contemporary Hospitality Management. 18(6), 482-495. https://doi.org/10.1108/09596110610681520

Yazıcığlu, Y. ve Samiye E. (2004). Spss uygulamalı bilimsel araştırma yöntemleri. Ankara: Detay Yayınc1lik.

Yuan, Y. E., \& Wu C.K. (2008). Relationship among experiential marketing, experiential value and customer satisfaction. Journal of Hospitality and Tourism Research. 32(3), 387-410. https://doi.org/10.1177/1096348008317392 